University for Business and Technology in Kosovo

UBT Knowledge Center

Oct 28th, 9:00 AM - Oct 30th, 5:00 PM

\title{
Effect of the Opening in Flat Slabs on Punching Shear Resistance According to EN 1992-1-1:2004
}

Xhemshir Mulliqi

University of Zagreb, xhemshir_mulliqi@yahoo.com

Follow this and additional works at: https://knowledgecenter.ubt-uni.net/conference

Part of the Engineering Commons

\section{Recommended Citation}

Mulliqi, Xhemshir, "Effect of the Opening in Flat Slabs on Punching Shear Resistance According to EN 1992-1-1:2004" (2016). UBT International Conference. 14.

https://knowledgecenter.ubt-uni.net/conference/2016/all-events/14

This Event is brought to you for free and open access by the Publication and Journals at UBT Knowledge Center. It has been accepted for inclusion in UBT International Conference by an authorized administrator of UBT Knowledge Center. For more information, please contact knowledge.center@ubt-uni.net. 
Effect of the Opening in Flat Slabs on Punching Shear Resistance According to EN 1992-

\title{
Effect of the Opening in Flat Slabs on Punching Shear Resistance According to EN 1992-1-1:2004
}

\author{
Xhemshir Mulliqi \\ University of Zagreb, Faculty of Civil Engineering \\ xhemshir_mulliqi@yahoo.com
}

\begin{abstract}
After the war in Kosovo is highlighted by the construction of reinforced concrete buildings with flat slabs with no beams and no enlarged column heads. These slabs are subjected to punching shear failure of slab-column connections. Load concentration around the column head generally leads to increased stresses which cannot be absorbed solely in thin slab thicknesses. The punching shear strength is an extremely significant parameter for the design of flat slabs. Solution of architecture often imposes the necessity of openings near the columns. In this paper will examine the effect of openings in different positions and with different dimensions in the punching shear strength. The calculations performed in the punching shear application are based on the standard EN 1992-1-1:2004.
\end{abstract}

Keywords: Flat slabs, Punching shear resistance, Opening, Punching shear capacity, Critical perimeters

\section{Introduction}

After the war in Kosovo buildings are often constructed using reinforced concrete flat slabs with no beams and no enlarged column heads combined with punctual supports such as columns of varying cross section and slenderness. The advantages of flat slabs are easy solution of architecture design that enables flexibility in the movement of non-structural walls in the desired position, easy placement of equipment, and installation underneath the slab. But these slabs are subjected to punching shear failure of slab-column connections. Load concentration around the column head generally leads to increased stresses which cannot be absorbed solely in thin slab thicknesses.

Punching shear has been the object of an intense experimental effort since the 1950s. During the 1960's and 1970's laboratory tests and extensive research were conducted. In most cases, the phenomenon is investigated by considering an isolated slab element.

Solution of architecture often imposes the necessity of openings near the columns .In this paper will examine the effect of openings in different positions and with different dimensions in the punching shear strength. The calculations performed in the punching shear application are based on the standard EN 1992-1-1:2004. 
Book of Proceedings

International Conference on Civil Engineering, Infrastructure and Environment

\section{Punching shear}

Punching shear is a phenomenon in flat slabs caused by concentrated support reactions inducing a cone shaped perforation starting from the top surface of the slab. Although generally preceded by flexural failure, punching shear is a brittle failure mode and the risk of progressive collapse requires a higher safety class in structural design.

This paper gives a brief overview of the research and how punching shear of reinforced concrete is accounted for in Eurocode 2 (EC2). Design for punching shear is covered in clause 6.4 of EN 1992$1-1$.

An appropriate verification model for checking punching failure at the ultimate limit state is shown in Figure 1.[1]

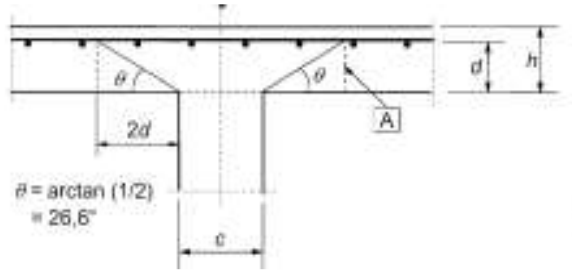

A. - basic contro sectian

Fig. 1. Verification model for punching shear at the ultimate limit state

The critical perimeter for slabs is placed at a distance of lcrit $=2.0 \cdot \mathrm{dm}$ from the column edge.
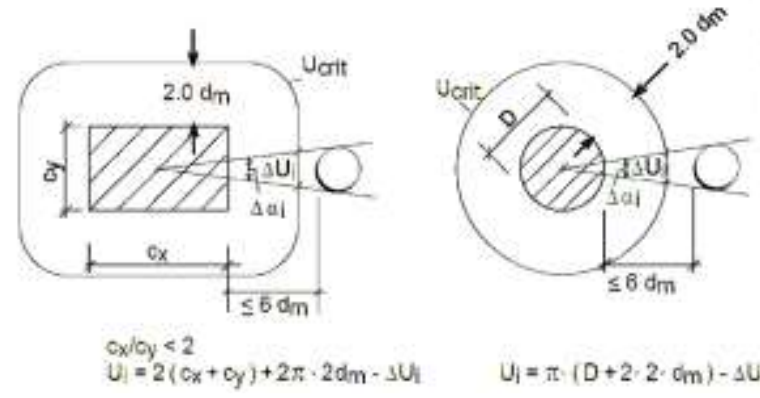

$$
U_{i}=2\left(c_{x}+c_{y}\right)+2 \pi \cdot 2 d m-3 U_{i} \quad U_{i}=\pi \cdot\left(D+2 \cdot 2 \cdot d_{m}\right)-\Delta U_{i}
$$

Fig. 2. Critical perimeter around load introduction areas according to EN 1992, 6.4.2

\subsection{Verification in the limit state}

Existing shear force in the ultimate limit state $\mathrm{v}_{\mathrm{Ed}}$ should not exceeded value of the maximum punching shear resistance $\mathrm{v}_{\mathrm{Rd} \text {,max }}$.

$$
\mathrm{v}_{\mathrm{Ed}}=\frac{\beta \cdot \mathrm{V}_{\mathrm{Ed}}}{\mathrm{u} \cdot \mathrm{d}_{\mathrm{m}}} \leq \mathrm{v}_{\mathrm{Rd}, \max } \quad\left[\mathrm{N} / \mathrm{mm}^{2}\right]
$$

$\beta=$ correction factor for non rotation-symmetrical load introduction $\mathrm{v}_{\mathrm{Ed}}=$ design value of the mean shear force applying in the considered perimeter $\mathrm{V}_{\mathrm{Ed}}=$ shear force in the ULS 
Effect of the Opening in Flat Slabs on Punching Shear Resistance According to EN 1992$1-1: 2004$

$\mathrm{u}=$ circumference of the considered perimeter minus the perimeter deduction due to the holes at a distance $<6 \cdot \mathrm{dm}$. In general, $\mathrm{u}=\mathrm{u}_{0}$, as per NA Germany $\mathrm{u}=\mathrm{u}_{1}$

$\mathrm{v}_{\mathrm{Rd}, \max }=$ maximum punching shear resistance

$$
\beta=1+\mathrm{k} \cdot \frac{\mathrm{M}_{\mathrm{Ed}}}{\mathrm{V}_{\mathrm{Ed}}} \cdot \frac{\mathrm{u}_{1}}{\mathrm{~W}_{1}}
$$

$\mathrm{w}_{1}$ corresponds to a distribution of shear as illustrated in Figure 2 and is a function of the basic control perimeter $\mathrm{u}_{1}$ :

$$
\mathrm{w}_{1}=\int_{0}^{\mathrm{u}_{1}}|\mathrm{e}| \mathrm{dl}
$$

For an internal rectangular column, coefficient $w_{1}$ is:

$$
w_{1}=\frac{c_{1}^{2}}{2}+c_{1} c_{2}+4 c_{2} d+16 d^{2}+2 \pi d c_{1}
$$

Where:

$\mathrm{c}_{1}$ is the column dimension parallel to the eccentricity of the load

$c_{2}$ is the column dimension perpendicular to the eccentricity of the load

For interior columns with a circular cross section, $\beta$ is applied:

$$
\beta=1,0+0,6 \pi \frac{\mathrm{e}}{D+2 \mathrm{l}_{\mathrm{u}}}
$$

For an internal rectangular column where the loading is eccentric to both axes, the following approximate expression for $\beta$ may be used:

$$
\beta=1+1,8 \sqrt{\left(\frac{e_{y}}{b_{z}}\right)^{2}+\left(\frac{e_{z}}{b_{z}}\right)^{2}}
$$

$e_{y}$ results from a moment about the $\mathrm{z}$ axis and $e_{z}$ from a moment about the y axis.

Table 2. Values for the aspect ratio factor, $\mathrm{k}[2]$

\begin{tabular}{cc}
\hline$c_{1} / c_{2}$ & $\mathrm{k}$ \\
\hline$\leq 0,5$ & 0.45 \\
1 & 0.60 \\
2 & 0.70 \\
$\geq 3$ & 0.80 \\
\hline
\end{tabular}

To take the eccentricity into account, a factor $\beta$ can be determined with simplified assumptions according to Chapter 6.4.3 (EC 2).[4]

\subsection{Design criteria as per EN 1992 without punching shear reinforcement}

Without punching shear reinforcement, the following condition must be satisfied in the control perimeter.

$$
\mathrm{v}_{\mathrm{Rd}, \mathrm{c}}=\left[\mathrm{C}_{\mathrm{Rd}, \mathrm{c}} \cdot \mathrm{k} \cdot\left(100 \cdot \rho_{\mathrm{I}} \cdot \mathrm{f}_{\mathrm{Ed}}\right]^{1 / 3}+\mathrm{v}_{\mathrm{Rd}, \mathrm{c}} \cdot \mathrm{K}_{\mathrm{cp}}\right] \geq\left(\mathrm{vmin}+\mathrm{k}_{1} \cdot \zeta_{\mathrm{cp}}\right)
$$

For foundations, the following condition applies:

$$
\begin{aligned}
& \mathrm{v}_{\mathrm{Rd}, \mathrm{c}}=\left[\mathrm{C}_{\mathrm{Rd}, \mathrm{c}} \cdot \mathrm{k} \cdot\left(100 \cdot \rho_{\mathrm{I}} \cdot \mathrm{f}_{\mathrm{ck}}\right]^{1 / 3} \cdot 2 \cdot \mathrm{d}_{\mathrm{m}} / \mathrm{a}\right] \geq\left(\mathrm{vmin} \cdot 2 \cdot \mathrm{d}_{\mathrm{m}} / \mathrm{a}\right) \\
& \mathrm{C}_{\mathrm{Rd}, \mathrm{c}}=0.18 / \gamma \mathrm{c}, \mathrm{k}_{1}=0.1 \quad \text { or as per NA }
\end{aligned}
$$

The effective height of the slab taken as the average of the effective depths in two orthogonal directions: 


$$
\begin{gathered}
\mathrm{d}_{\mathrm{m}}[\mathrm{mm}]=\frac{\mathrm{d}_{\mathrm{m}, \mathrm{x}}+\mathrm{d}_{\mathrm{m}, \mathrm{y}}}{2} \\
\mathrm{k}=1+\sqrt{\frac{200}{\mathrm{~d}_{\mathrm{m}}}} \leq 2,0 \\
\operatorname{vmin}=0,035 \cdot \mathrm{k}^{1,5} \cdot \mathrm{f}_{\mathrm{ck}} 0,5
\end{gathered}
$$

Average longitudinal reinforcement ratio $\rho_{\mathrm{I}}$ in the examined perimeter is

$$
\rho_{\mathrm{I}}=\sqrt{\rho_{\mathrm{Ix}} \cdot \rho_{\mathrm{Iy}}} \leq 0,02
$$

$\sigma_{\mathrm{cd}}=$ design value of the axial concrete stress in $\left[\mathrm{N} / \mathrm{mm}^{2}\right]$ inside the examined perimeter:

$$
\begin{gathered}
\sigma_{\mathrm{cd}}=\frac{\sigma_{\mathrm{cd}, \mathrm{x}+} \sigma_{\mathrm{cd}, \mathrm{y}}}{2} \\
\sigma_{\mathrm{cd}, \mathrm{x}}=\frac{\mathrm{N}_{\mathrm{Ed}, \mathrm{x}}}{\mathrm{A}_{\mathrm{c}, \mathrm{x}}} \quad \text { and } \quad \sigma_{\mathrm{cd}, \mathrm{y}}=\frac{\mathrm{N}_{\mathrm{Ed}, \mathrm{y}}}{\mathrm{A}_{\mathrm{c}, \mathrm{y}}}
\end{gathered}
$$

$\sigma_{\mathrm{cd}}(+=$ compression, $-=$ tensile stress $)$ sign as per EN 1992, $0.0 \leq \sigma \mathrm{cd} \leq 2.0 \mathrm{~N} / \mathrm{mm}^{2},[3]$

\subsection{Design criteria as per EN 1992 with punching shear reinforcement}

Punching shear reinforcement is required, if the following applies:

$$
\mathrm{v}_{\mathrm{Rd}, \mathrm{c}} \leq \mathrm{v}_{\mathrm{Rd}, \mathrm{cs}} \leq \mathrm{v}_{\mathrm{Rd} \text {,max }}
$$

The following equation as per EN 1992 (6.52) applies to each reinforcement row:

$$
\mathrm{v}_{\mathrm{Rd}, \mathrm{cs}}=0,75 \cdot \mathrm{v}_{\mathrm{Rd}, \mathrm{c}}+1,5 \cdot \frac{\left(\frac{\mathrm{d}}{\mathrm{s}_{\mathrm{r}}}\right) \cdot \mathrm{A}_{\mathrm{sw}} \cdot \mathrm{f}_{\mathrm{ywd}, \mathrm{ef}}}{\mathrm{u}_{1} \cdot \mathrm{d}_{\mathrm{m}}} \cdot \sin (\alpha)
$$

$\mathrm{v}_{\mathrm{Rd}, \mathrm{c}}=$ supporting portion of the concrete in the critical perimeter

$\mathrm{A}_{\mathrm{sw}}=$ cross-sectional area of the existing reinforcement per row

$\mathrm{u}=$ circumference of the critical perimeter minus the perimeter deduction due to the holes at a distance $<6 \cdot \mathrm{d}_{\mathrm{m}}$

$s_{\mathrm{r}}=$ effective width of one single reinforcement row; $\mathrm{sr} \leq 0,75 \cdot \mathrm{d}_{\mathrm{m}}$

$$
\begin{gathered}
\mathrm{v}_{\mathrm{Rd}, \max }=0,4 \cdot v \cdot \mathrm{f}_{\mathrm{cd}} \\
v=0,6 \cdot\left(1-\mathrm{f}_{\mathrm{ck}} / 250\right)
\end{gathered}
$$

\subsection{Reinforcement cross section required by EN 1992}

From equation (18) to obtain $\mathrm{A}_{\mathrm{sw}}$

$$
\text { req. } A_{s w}=\frac{\left(V_{E d, c s}-0,75 \cdot V_{R d, c}\right) \cdot u_{1} \cdot d}{1,5 \cdot\left(d / s_{r}\right) \cdot f_{y w d, e f} \cdot \sin (\alpha)}
$$

\section{Holes (Openings)}


Effect of the Opening in Flat Slabs on Punching Shear Resistance According to EN 1992$1-1: 2004$

Holes can be taken into consideration with all kinds and types of columns. The sum of the length deductions $\Delta \mathrm{Ui}[\mathrm{cm}]$ describes the section of the inner perimeter at a distance of $1.5 \cdot \mathrm{d}_{\mathrm{m}}$ that is limited by the intersecting tangents of the cut-outs running from the column's centre of gravity to the cut-out perimeters.

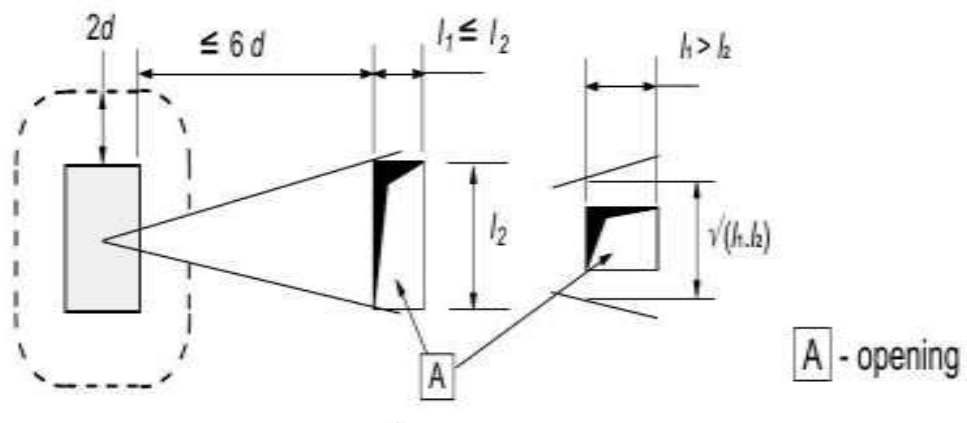

Fig.3. Control perimeter near an opening

\section{Case Study concrete slab with openings}

The case study considers a concrete slab thickness of $20 \mathrm{~cm}$ with the concrete strength class C25/30 and the reinforcing steel B500B. Shear force resultant in the perimeter around the column is used $\mathrm{V}_{\mathrm{Ed}}=365.3 \mathrm{Kn}$ which corresponds to realistic value in residential buildings using reinforce .We will examine the effect of openings in the punching shear strength with dimensions $15 / 15 \mathrm{~cm}$ and $40 / 40 \mathrm{~cm}$ in different positions with $\rho=0.2 \%$ and $\rho=0.93 \%$ as shown in Table 2. and (Fig.4) .The dimensions for square column is $40 \mathrm{~cm}$ while for circular column is $\emptyset 40 \mathrm{~cm}$.

Table 2. The effect of openings in different positions and with different dimensions in the punching

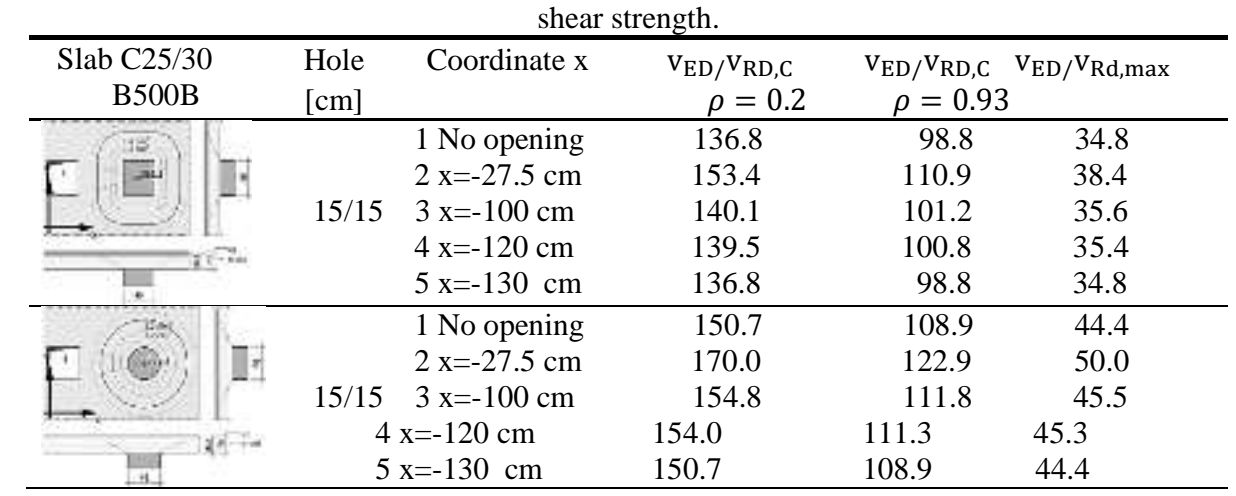


Book of Proceedings

International Conference on Civil Engineering, Infrastructure and Environment

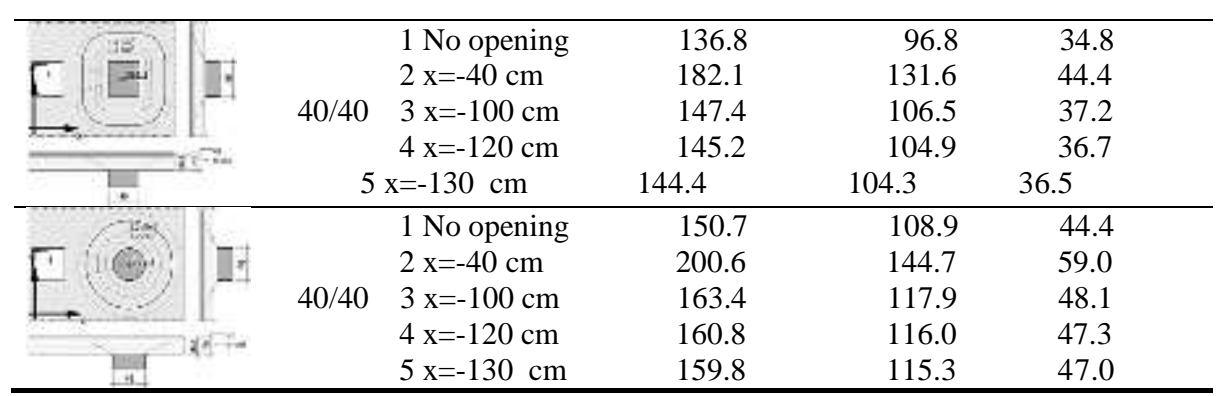
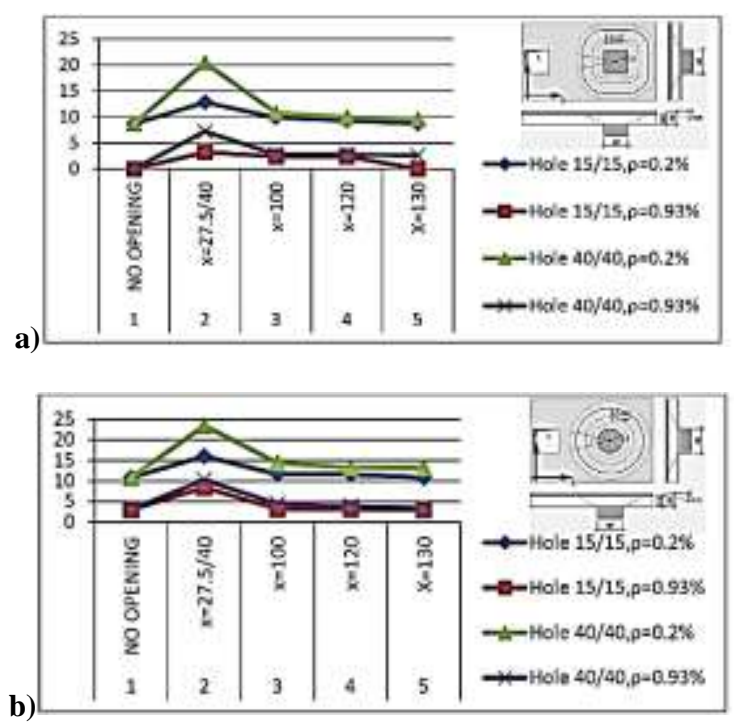

Fig. 4. Punching shear reinforcement depending from opening size in slab and average longitudinal reinforcement a) rectangular intern column $40 / 40 \mathrm{~cm}$;b) circular column $\emptyset 40 \mathrm{~cm}$

\section{Conclusions}

In accordance with EN 1992, holes with a distance to the column edge smaller than $6 \cdot \mathrm{dm}$ are considered as decisive. The opening size and its distance from the face of columns and reinforcement ratio, have the significant influence on the punching shear resistance. The table 2 show that the punching shear resistance is inversely proportional to distance of the opening. Figure 4 shows the required punching shear reinforcement with vertical stirrups, for opening size $15 / 15 \mathrm{~cm}$ and $40 / 40 \mathrm{~cm}$ for different distance of opening from the face of columns with average longitudinal reinforcement $\rho=0.2 \%$ and $\rho=0.93 \%$. The required punching shear reinforcement area is inversely proportional with reinforcement ratio $\rho$. 
Effect of the Opening in Flat Slabs on Punching Shear Resistance According to EN 1992$1-1: 2004$

The shape of the columns, i.e. square or circular, influence in the punching shear strength. The square columns had about $10 \%$ higher punching shear strength than the circular columns.

\section{References}

1. EN 1992-1-1 (2004) (English): Eurocode 2: Design of concrete structures - Part 1-1: General rules and rules for buildings [Authority: The European Union Per Regulation 305/2011, Directive 98/34/EC, Directive 2004/18/EC]

2. R S Narayanan and a Beeby: Designers' Guide to EN 1992-1-1 and EN 1992-1-2 Eurocode2: Design of Concrete Structures. General rules and rules for buildings and structural fire design, London (2005)

3. Draft for Booklet 600, Erläuterungen zu Eurocode 2, DafStb

4. F.Biasioli, G.Mancini, M.Just, M.Curbach, J.Walraven, S.Gmainer, J.Arrieta, R.Frank, C.Morin, F.Robert: EUROCODE 2: BACKGROUND\&APPLICATIONS DESIGN OF CONCRETE

BUILDINGS: Luxembourg: Publications Office of the European Union,(2014) 